\title{
ANTECEDENTS OF ORGANIZATIONAL CITIZENSHIP BEHAVIOUR AMONG PUBLIC / CIVIL EMPLOYEES: A SCOPING REVIEW
}

\author{
Razima Hanim Osman ${ }^{1}$ \\ Awang Had Salleh Graduate School, Universiti Utara Malaysia. \\ (Email: razimahanim@ums.edu.my) \\ Mariny Abdul Ghani2 \\ School of Applied Psychology, Social Work and Policy, Universiti Utara Malaysia. \\ (Email: mariny@uum.edu.my) \\ Norzaliza Alis $^{3}$ \\ School of Applied Psychology, Social Work and Policy, Universiti Utara Malaysia. \\ (Email: nzaliza@uum.edu.my)
}

Received date: 28-08-2019

Revised date: 08-09-2019

Accepted date: 10-09-2019

Published date: 15-09-2019

To cite this document: Osman, R. H., Abdul Ghani, M., \& Alis, N. (2019). Antecedents of Organizational Citizenship Behaviour Among Public / Civil Employees: A Scoping Review. International Journal of Education, Psychology and Counseling, 4 (32), 338-350.

DOI: $10.35631 / \mathrm{IJEPC} .4320029$

\begin{abstract}
Organizational citizenship behaviour $(O C B)$ throughout literature provides evidence in increasing organizational welfares as well as its employees' welfares. It is important to understand the reasons behind the occurrence of $O C B$ in order to increase the likelihood of employees to engage in OCB. Moreover, it is important for public/ civil employees to engage in $O C B$ as they provide services to meet societal needs and demands. The present article set out to analyze the existing literature on the OCB's antecedents among public/ civil employees in Asian contexts. Guided by the scoping review method, a review of the SCOPUS, ProQuest and MyJurnal databases identified 20 related studies. Further review of these studies resulted in categorizing the antecedents in three settings - law enforcement and military settings, nurses and public health settings and lastly office-based settings. The antecedents were discussed based on the four main domains - employee characteristic, task characteristics, organizational conditions, and leadership behaviour. The review also suggests to investigate further and integrated with other variables which moderating or mediating the relationships between the antecedents and $O C B$.
\end{abstract}

Keywords: Organizational Citizenship Behaviour, Public Employees, Civil Servants

\section{Introduction}

For the past 20 years, organizational citizenship behaviour (OCB) gains its relevancy not only in the field of psychology but also in management (Jehad Mohammad, Farzana Quoquab Habib $\&$ Mohmad Adnan Alias, 2011). There were 577 articles related to OCB found in the SCOPUS 
database since 1999 until 2019. The significant of its relevancy is due to its contribution to the efficiency of organizational functioning in terms of increasing work productivity, work engagement as well as work satisfaction (Basu, Pradhan, \& Tewari, 2017; Lavy \& LittmanOvadia, 2016). Moreover, based on the latest systematic review done by Atatsi, Stoffers, and Kil, (2019), most of the studies found a positive relationship between OCB and employees performance. According to Organ (1997), organizational citizenship behaviour (OCB) is defined as behaviours that act spontaneously or discretionarily by the employees whereby these behaviours are beyond prescribed behaviours stated in the job descriptions. Not only OCB has proven to increase the organizational efficiency but also increasing the feeling of vigour and meaningfulness of work at the end of day thus contributing to a positive well-being among employees (Lam, Wan \& Roussin, 2016).

The contributions toward organizational efficiency and employees' positive well-being are the crucial factors for the OCB to be nourished among public or civil employees. Nowadays, with the rapid growth of the technologies development, variety of socioeconomic needs to be catered as well as to compete with the performance and efficiency of private or public organizations of other countries (Kim, 2012; Subramaniam Sri Ramalu \& Zulhusni Mohamad Rashid, 2017), public organizations need to step out from the traditional bureaucratic systems and moving to innovative transparency systems. In order for this transformation to happen, lies in the engagement of OCB among public or civil employees. OCB is able to give a positive impact on public service outcomes by reducing public bureaucracy thus performing a better quality of service (Vigoda-Gadot \& Beeri, 2012).

\section{Background}

\section{Organizational Citizenship Behaviour (OCB)}

The originality of organizational citizenship behaviour (OCB) was taken from Katz's idea of what motivates people to engage in the positive organizational behaviour. He curious of what makes people become efficient to function as a unit in an organization and he started to investigate the types of behaviour that led to this efficiency as well as the conditions that triggered the motivational patterns in the organizational context (Katz, 1964). As a result of Katz's ideology, researchers began to shift the attention from formal work behaviours to the studies on discretionary behaviours. The shift led to the discovery of prosocial behaviours in the organization, organizational spontaneity, extra-role behaviours and organizational citizenship behaviour (OCB) (Smith, Organ and Near, 1983; George and Brief, 1992; Organ, 1997).

Similarly to Katz's spontaneous behaviours, the citizenship behaviour was also identified as behaviour that go beyond formal role specification and difficult to measure as the behaviours maybe subtle and unnoticed by the formal appraisal used by the organization (Smith, Organ \& Near, 1983). In the beginning there were two dimensions (altruism and generalized compliance) represented in OCB (Smith et. al, 1983). The dimensions later expanded when Organ (1988) used five dimensions (altruism, courtesy, conscientiousness, sportsmanship and civic virtue) to describe OCB. There were almost 30 different dimensions of citizenship behaviour used in many previous studies which led to similarity and redundancy in characteristic to one another (Podsakoff, MacKenzie, Paine, \& Bachrach, 2000). Due to the redundancy, Podsakoff and colleagues (2000) identified seven main dimensions (altruism, organizational compliance, sportsmanship, organizational loyalty, individual initiative, civic virtue and self-development) in their meta-analysis study. 
Though many dimensions emerged from different studies, altruism appeared to be the most important dimension in OCB that focused on helping behaviour aimed directly to the specific person (Smith et. al, 1983).In fact, they explained that the behaviour that has altruistic nature motivates people to help others voluntarily and out of self-interest (Smith et. al, 1983). In an organizational context, employees with altruistic characteristics have been linked to engaging in behaviour that is beyond the formal role specification where they provided voluntarily help for others or preventing the occurrence of work-related problems (Podsakoff, et. al., 2000). Moreover, employees with high altruism support their colleagues by spreading and sharing the best practice throughout the department thus together increase the work productivity (Podsakoff \& MacKenzie, 1997). Not only that, the organization is also receiving the benefit of having altruism among employees in which the altruistic character influences other positive attitudinal behaviours such as morale and group cohesiveness thus helping the organization to maintain as well as to attract the best employees working in the organization (Podsakoff et al., 2000).

In relation to the effect of OCB on employees in which the effects would help employees to engage in more positive attitudes and behaviours, there were many studies which examined of what might influence the existence of OCB. According to Podsakoff and colleagues (2000), there were four categories of antecedent domains that might influence the occurrence of OCB (refer to Table 2). The first category of domain was employees' characteristics which refer to employees' attitudinal concepts such as employees' morale, satisfaction, and commitment (Shim and Rohrbaugh, 2014; Kim, Park and Chang, 2011). The second domain was task/ job characteristics where the conditions of the tasks may influence the occurrence of OCB. Task feedback and task importance were the examples of studies fall under the second domain of antecedents. The third domain was organizational characteristics where group cohesiveness and perceived organizational support were studied under this category of the antecedent (Wu and Liu, 2014; Chiaburu, Chakrabarty, Wang and Li, 2015). The fourth domain was leadership behaviours where different types of leadership were tested as the cause for employees to engage in OCB.

\section{Table 1: Definition of Each OCB's Dimensions}

\begin{tabular}{ll}
\hline \multicolumn{1}{c}{ Dimension } & \multicolumn{1}{c}{ Explanation } \\
\hline Altruism or Helping behaviour & $\begin{array}{l}\text { Aiding someone voluntarily or avoiding any work-related } \\
\text { incident from happening. }\end{array}$ \\
General/ Organizational & $\begin{array}{l}\text { The acceptance of rules and regulations where the } \\
\text { compliance continues even when no one monitors. } \\
\text { Compliance }\end{array}$ \\
Avourtesy & $\begin{array}{l}\text { Aviding and preventing conflict to occur in work } \\
\text { relationship. }\end{array}$ \\
Dedication to do more than formal basic requirements in \\
the tasks or job.
\end{tabular}


Individual Initiative

Self-Development
Giving extra effort in engaging task-related behaviour by surpassing the minimal or required requirement.

Giving the effort to improve one's capabilities, skills and knowledge for the sake to improve organizational effectiveness.

Table 2: Antecedents of OCB

\begin{tabular}{|c|c|}
\hline Domain & Explanation \\
\hline Employee characteristics & $\begin{array}{l}\text { Variables that come from the individuals themselves } \\
\text { which consist of employee attitudes, dispositional } \\
\text { variables, employee role perceptions demographical } \\
\text { variables as well as employee abilities and individual } \\
\text { differences. }\end{array}$ \\
\hline Task/ Job characteristics & $\begin{array}{l}\text { Variables that come from the work features or design such } \\
\text { as task feedback, task routinization and intrinsically } \\
\text { satisfying task. }\end{array}$ \\
\hline Organizational conditions & $\begin{array}{l}\text { Variables that come from the conditions or surrounding of } \\
\text { the organization or place at work such as organization } \\
\text { formalization, organizational flexibility, advisory/ staff } \\
\text { support, as well as perceived organizational support. }\end{array}$ \\
\hline Leadership behaviours & $\begin{array}{l}\text { Variables that come from individuals that lead the group } \\
\text { or organizations such as transformational leadership, } \\
\text { transactional leadership and Path-Goal theory of } \\
\text { leadership }\end{array}$ \\
\hline
\end{tabular}

Source: Podsakoff, MacKenzie, Paine and Bachrach (2000) meta-analysis study.

\section{Organizational Citizenship Behaviour (OCB) among Public or Civil Employees}

The terms of public employees or civil servants are used interchangeably which referring to those who were hired by federal, state, province and municipal governments and works in a non-profit organization that are highly affect society's everyday life such as education, health, law enforcement etc. As all public organizations and governments around the world are working hard to maintain a good performance, issues such as incompetency and inefficiency of its employees are still an uphill battle to overcome (Ayu Kamareena Abdullah Thani \& Abdul Kadir Othman, 2018; Kim, 2012). Furthermore, the public nowadays are more attentive and aware of their rights by demanding for more transparency processes and procedures in decision making made by the public organizations and government in their services (Ibrahim, Aziz Amin, Ghani Hashim \& Salleh, 2015).

In order to provide multifarious services as to meet with societal needs and demands, and also to increase efficiency in performance, public employees need to broaden the scope by not only focusing on what stated in the job descriptions but also strengthening the social system within the organization by engage in OCB. Previous researches showed that OCB benefits both employees and the organizations by increasing the level of employees' well-being, work satisfaction, customer satisfaction, work productivity and the quality of work performance (Basu et. al., 2017; Lavy et. al., 2016; Noorlaila Yunus \& Cairul Azwa Azimi, 2016; Subramaniam Sri Ramalu et. al., 2016). Therefore, it is essential for the civil or public employees to be equipped by OCB in which the behaviours contributes to support the in-role performance and move toward a higher quality of public service delivery. 
Despite of the importance for public organizations to equip its employees with discretionary behaviours, there has been a limited study done in examining these behaviours in the concept of organizational citizenship behaviour (OCB) among civil employees. Paillé et al. (2015) have mentioned that further study needs to be conducted in examining variables connections with OCB among civil/public employees. Therefore, this study attempts to fill in the gap by understanding and contributing literature related to OCB in civil/ public services. Apart from that, this study examines the antecedents that influence the occurrence of OCB among public employees in Malaysia and other Asian countries.

\section{Aim of The Study}

The purpose of this scoping review study was to investigate current existing literatures related to the organizational citizenship behaviour (OCB) among the civil or public employees in Asian countries. Research question stated in this study was what are the antecedents that are likely to influence public employees to engage in OCB based on different work setting in Malaysia and other Asian countries?

\section{Methods}

In this section the method used to retrieve articles related to organizational citizenship behaviour among civil or public employees is discussed. The section is discussed on scoping review processes which include identification and screening processes, resources to retrieve the articles, eligibility and exclusion criteria.

\section{Scoping Reviews Process}

Scoping reviews are one of the methods that collects relevant literatures as it provides an overview of a topic which the researchers have selected (Jacobs, 2016; Peterson, Pearce, Ferguson, \& Longford, 2017). Though scoping reviews processes was published in 2005 (Arksey \& O’Malley. 2005), it still considered as a new methodology in which the definition and procedures used to derived the selection of articles in this processes were still diverse and unspecified (Peters, Godfrey, Hanan Khalil, McInerny, Parker \& Soares, 2015; Peterson, et. al, 2017).

According to Arskey and O'Malley (2005), there are five steps in scoping review processes. First, identifying the research questions in which these research questions focused on the selected variables thus narrowing down the search strings that would be included in the study (see Table 3). Secondly, identifying the relevant studies in which choosing resources of databases in selecting published research articles (see Fig. 1). At this stage, there were 245 articles based on the search string used in three databases (SCOPUS, ProQuest and MyJurnal). Third related to study selection which includes eligibility and exclusion criteria. By this stage, screening was applied and after reading and examining full articles, 188 were excluded as some did not focus on the public services. Using eligibility to narrowed down the selection into 20 articles. Fourthly, charting the data by categorizing 20 articles into two tables (OCB conducted in Asian counties and OCB conducted in Malaysia) under the headings: authors and date, research objective, research design, country of origin, sample and findings (see Table 4). Lastly organizing, summarizing and reporting the data. 
TITLE-ABS-KEY ("organi*ational citizenship behavio?r” OR "organi*ational citizenship performance" OR "prosocial organi*ational behavio?r" OR "extra role behavio?r") AND ("public employee\$” OR “public servant\$” OR “public worker\$” OR "public personnel\$” OR “civil employee\$” OR civil servant\$" OR “civil worker\$" OR “civil personnel\$" OR "government employee\$” OR “government servant\$” OR "government worker\$” OR "government personnel\$”)

\section{Resources}

The reviews were based on three journal databases - Scopus, ProQuest and MyJurnal. SCOPUS is the first database used in this study as it is the largest abstract and citation database of peer-reviewed literatures with various multi-discipline fields including sciences, social sciences, art and humanities, technologies and medicine. ProQuest is frequently used by the researchers and learning communities as it is a database that assembles billions of vetted and indexed documents including scholarly journals, working papers, newspaper reports and eBooks. Lastly, MyJurnal was selected in this study as it contains bibliographic data and full contents of articles published in refereed journals in Malaysia with various disciplines.

\section{Eligibility and Exclusion Criteria}

There were four criteria of eligibility and exclusion used to guide the selection of articles in this study. First related to the literature or document type in which only journal (research articles) are selected whereas review article, books, proceeding papers and thesis/ dissertation are all excluded. Second related to the language type in which to avoid any misinterpretation and confusion in terminologies, this study excluded non-English publication and selected only English written research articles. Third, with regard to timeline, this study selected articles published in a period of 10 years (between 2009- 2019) as to track the current views and perspectives of the variables. Lastly, the countries and territories chosen in this study are based on the Asian territories/ countries (South East Asia, South Asia, Central Asia, West Asia, and East Asia) as this study focused on the study of OCB among Asian samples (see Table 5). 


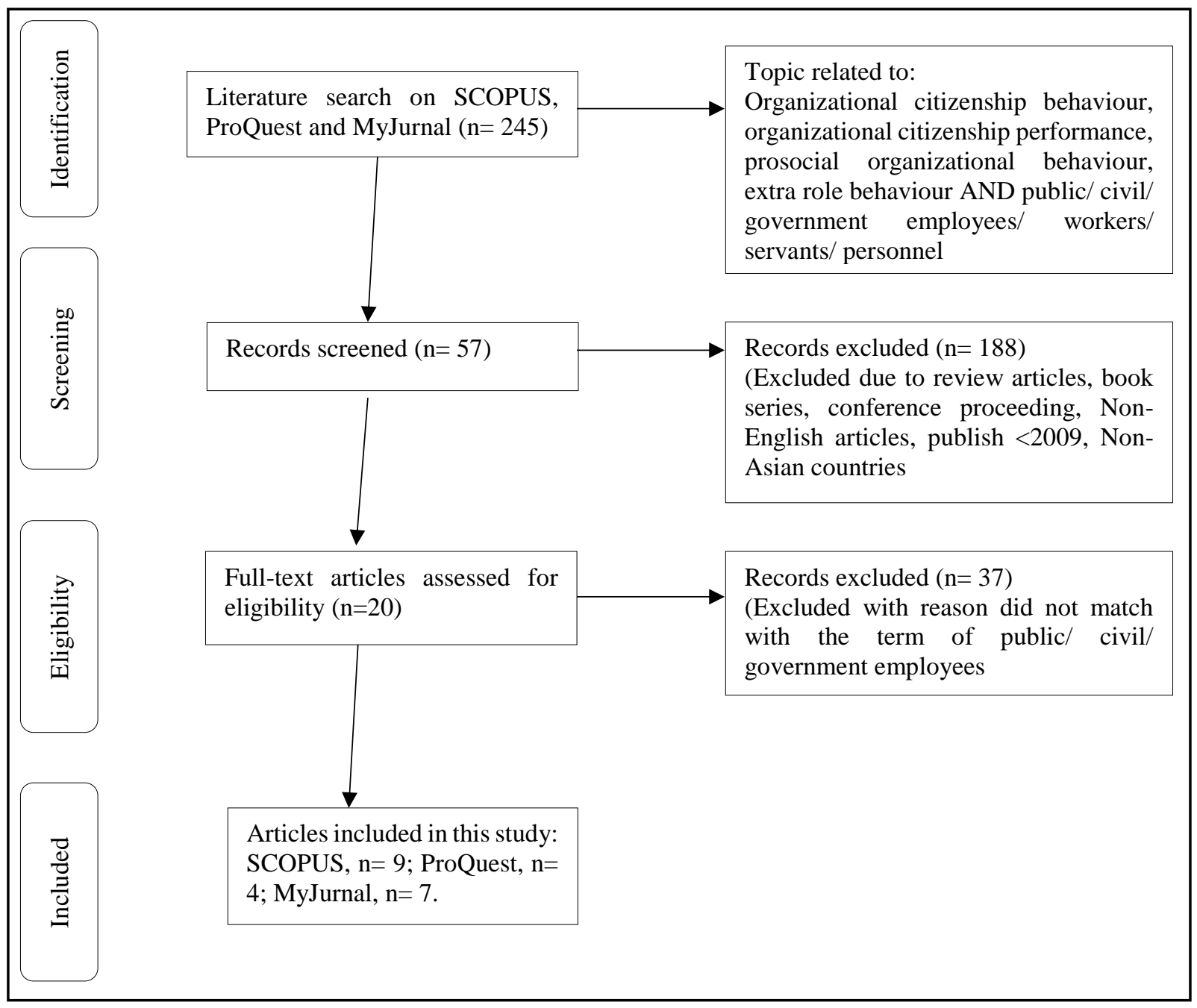

Figure 1: The Flow Diagram of The Study

Table 5: Eligibility and Exclusion Criteria

\begin{tabular}{|c|c|c|}
\hline Criterion & Eligibility & Exclusion \\
\hline Literature type & Journal (Research articles) & $\begin{array}{c}\text { Journal (reviews articles, books, } \\
\text { proceeding papers, dissertation/ } \\
\text { thesis) }\end{array}$ \\
\hline Language type & English & Non-English \\
\hline Timeline & 2009-2019 (10 years) & $<2009$ \\
\hline $\begin{array}{c}\text { Countries and } \\
\text { territories }\end{array}$ & Asian countries & Non-Asian countries \\
\hline
\end{tabular}

\section{Findings and Discussions}

The review resulted of four Asian territories that related to the study of OCB among public employees. The four Asian territories are West Asia (Turkey and Israel), East Asia (Taiwan, South Korea and China), South Asia (India and Iran) and lastly South East Asia (Malaysia). Based on the 20 articles selected, three studies focused on OCB among public employees in Taiwan (Kao, 2017; Hsiung, Lin \& Lin, 2011; Tsai \& Wu, 2010), three studies on OCB among South Korea's public employees (Campbell, 2015; Park, Park \& Ryu, 2013; Kim, 2012), two studies on OCB among China's public employees (Cun, 2012; Chih, Yang \& Chang, 2012), 
one study each on OCB among public employees in India (Mohit Yadav \& Santosh Rangnekar, 2016), Iran (Fakhredin Taghinezhad, Mahboobe Safavi, Afsaneh Raiesifar \& Sayed Hossein Yahyavi, 2015), Turkey (Mukaddes Yesilkaya \& Peruzet Aydin, 2016), and Israel (Vashdi, Vigoda-Gadot \& Shlomi, 2012). Meanwhile, eight studies that focused on OCB among Malaysia's public employees were selected and compared to other Asian countries (Ayu Kamareena Abdullah Thani \& Abdul Kadir Othman, 2018; Junaidah Yusof, Hashim Fauzy Yaacob \& Siti Aisyah Abd Rahman, 2018; Nik Nadian Nisa Nik Nazli \& Sheikh Muhamad Hizam Sheikh Khairudin, 2018; Subramaniam Sri Ramalu \& Zulhusni Mohamad Rashid, 2017; Noorlaila Yunus \& Cairul Azwa Azmi, 2016; Ibrahim, Aziz Amin Ghani, Hashim \& Salleh, 2015; Fatimah, Amiraa \& Halim, 2011; Jehad Mohammad, Farzana Quoquab Habib \& Mohmad Adnan Alias, 2011).

Most of the studies (18 studies) applied quantitative methods in which the studies opt to use questionnaire surveys in collecting data on OCB while two studies used mixed methods (interview and questionnaire) approach. Regarding the year of publication, three was published in 2018, two were published in 2017, three each were published in 2016 and 2015, one was published in 2013, four were published in 2012, three were published in 2011 and lastly one was published in 2010 .

\section{OCB among Civil Law Enforcement and Military Settings}

The first review focuses on a study done by Kao (2017) on national immigration employees in Taiwan. An immigration employees is under the civil law enforcement in which they cover the rules of visa and passports entries, detecting and detaining those who breached the border and breaching immigration laws. Due to the immigration employees' work characteristics, engage in OCB is advantageous for border administration to run smoothly as well as moving toward more client-friendly administration. Therefore, based on Kao's study, transformational leadership was a significant antecedent to sustain the change-oriented OCB (Kao, 2017). Moreover, Kao found out that organization climate strengthened the relationship between transformational leader and change-oriented OCB (Kao, 2017). This means that though OCB exhibit on the individual basis, organization plays a vital role in influencing the positive behaviours among employees through a good example of leadership skills as well as promoting a positive organization climate.

Apart from that, the study showed that knowledge-oriented work characteristics (KOWCs) was also a significant antecedent for change-oriented OCB and the relationship of both variables was strengthened with self-efficacy as its mediator (Kao, 2017). This showed that in order to enrich the OCB among employees require the employees themselves to have a certain set of skills and knowledge to which they have confident in completing their tasks at work. This also proves that not only the organizational-level of antecedent contributes to OCB but also the individual-level of antecedent such as KOWCs and self-efficacy can influence OCB among public employees.

Another highlight for individual-level of antecedents for OCB can be seen in a study done among employees of Malaysia Civil Defense Force (APM) (Nik Nadian Nisa Nik Nazil \& Sheikh Muhamad Hizam Sheikh Khairudin, 2018). APM is responsible to perform the disaster relief work by providing protection and safety of person, society as well as property. Based on the characteristic of their job, it is a must for the APM's employees to have a set of knowledge, skills and abilities pertaining to disaster relief work. These set of knowledge, skills and abilities are not only to deliver the in-role related performance but also to strengthen the OCB among employees. This was supported in their study which showed that transfer of training (ToT) have 
a significant influence on OCB among the APM's employees (Nik Nadian Nisa Nik Nazil et. al, 2018). Moreover, ToT mediated between training simulation and OCB as well as relationship between work engagement and OCB (Nik Nadian Nisa Nik Nazil et. al, 2018). This means that the individual-level of antecedent such as ToT contributes to the enhancement of OCB among public employees.

Another antecedent that contributes to the occurrence of OCB is job satisfaction. Job satisfaction in general is the result of a good relationship between the employees with their work environment. This means that job satisfaction occurs when the employees like their job (difficulty of the tasks, role, and wages) and their work environment (supervisor, colleagues, clients, organization's rules and regulations). The relationship between job satisfaction and OCB can be seen in a study among 450 Republic of China Armed Force where the soldiers would engage in OCB whenever they felt satisfied in their jobs (Chih, et. al, 2012). Chin's study supported the previous meta-analysis which showed consistently significant connection between job satisfaction and OCB (Podsakoff, et.al., 2000).

However, in a study done by Hsiung et. al, (2011) among police officers, job satisfaction failed to increase the performance of $\mathrm{OCB}$, whenever there was a high level of perception of organizational politics (POP) among the employees. This means that whenever there is unfair and unhealthy organizational politics occurred, it would reduce the level of job satisfaction thus inhibit employees to engage in OCB. Having said that, Hsiung and collegues (2012) found out that POP has a positive relationship with OCB when the relationship was mediated by careerism. This showed that the employees believed that the advancement in organization was based on the personal connections rather than on competency thus want to perform OCB to the individuals who can fulfil the advancement.

Based on the reviews of OCB in the civil law enforcement and military setting, employee's characteristics domain such as employee attitudes (satisfaction, fairness, and commitment) and employee abilities and individual differences (knowledge, skills, ability, transfer of training) were examined. Apart from employee's characteristics domain, leadership behaviour was also found to be influential toward OCB. Leaders play a major role in this setting because the flow of communication in this setting is mostly from top to down delivery of communication. Leaders play an influential role on subordinates. Therefore review found that leadership behaviour such as transformational leaders was a significant predictor to encourage subordinates to engage in OCB.

\section{OCB among Nurses and Public Health Settings}

Another review of OCB focused among the nurses in public health setting. Nurse is a profession that focused on the care of individuals and communities ranging from ensuring the most accurate diagnosis to promoting and educating the public with health issues as to ensure the communities have a better quality of life. Having said that, the element of OCB is seen as an important behaviour that need to be nourished among the nurses and public health officers as it increases the quantity and the quality levels of caring behaviours (Taghinezhad, et. al, 2015). It is therefore important to identify factors that lead and promote OCB among nurses and public health officers.

Most of the OCB studies in public organizations focused on the variables in the employee characteristics' domain (Shim \& Rohrbaugh, 2014). This was also found in the nurse and public health settings whereby employee attitudes such as organizational commitment was positively related to OCB (Fakhredin Taghinezhad, et. al, 2015). This indicates that nurses who feel more 
commitment and dedication to the organization would perform OCB than nurses who have low level of commitment. Another variable in the employee characteristics' domain that was found relevant to OCB in this setting is demographical variables such as age, gender, tenure and others.

Having said that, a study found that age and position held in the public health organizations influenced the engagement of OCB in which nurses who were 36 to 40 years old rated more highly in OCB than those who were below 36 years old (Tsai \& Wu, 2010). Apart from that, nurses who held leader and supervisory positions were rated higher than those general nurses (Tsai \& Wu, 2010). The discovery in Tsai and Wu's study refuted the general findings in the meta-analysis study by Podsakoff et. al. (2000) which stated that in general, the demographical variables did not have any relationship with OCB. The differences of findings can based on variety of factors such as contextual, environmental and even cultural differences may influence how employees rated OCB (Fakhredin Taghinezhad, et. al, 2015).

Apart from employee characteristics' domain, organizational conditions domain influence the likelihood for employees to perform OCB. A study found that organizational justice has a significant impact on OCB among nurses (Fakhredin Taghinezhad, et. al, 2015). They further explained that procedural justice which is one of the type in organizational justice was the strongest antecedent of OCB (Fakhredin Taghinezhad, et. al, 2015). This means that the nurses who have a perception that the organization involved in fair processes in distributing any type of outcomes would engage more in OCB.

Another antecedents which have significant influence on OCB are workplace spirituality and motivation. Based on a study done by Junaidah Yusof, et. al, (2018), workplace spirituality which consists of meaningful work, sense of community and organizational values alignment predict significantly to OCB. This indicates that nurses who have their purposes in their working lives and align with the organization's values would go beyond the formal requirement of work behaviours. Another study done by Noorlaila Yunus, et. al, (2016) showed that employees who are motivated will more likely to perform any type of extra-role behaviours such as OCB. They found that Herzberg's motivator factor (achievement and growth components) strongly predicts in altruism, conscientiousness and courtesy components in OCB (Noorlaila Yunus, et. al, 2016). 
Table 4: Studies of OCB Conducted in Asia Countries

\begin{tabular}{|c|c|c|c|c|c|c|}
\hline No. & $\begin{array}{c}\text { Author and } \\
\text { date }\end{array}$ & Research objectives & Research design & $\begin{array}{l}\text { Country } \\
\text { of origin }\end{array}$ & Sample & Findings \\
\hline 1 & $\begin{array}{l}\text { Rui-Hsin } \\
\text { Kao, } 2017\end{array}$ & $\begin{array}{l}\text { The author wanted to } \\
\text { study change-oriented } \\
\text { OCB at the individual } \\
\text { level (knowledge- } \\
\text { oriented work } \\
\text { characteristics; KOWCs } \\
\text { and self-efficacy) as } \\
\text { well as at the group level } \\
\text { (transformational and } \\
\text { leadership aral ande) } \\
\text { organizational climate }\end{array}$ & $\begin{array}{lr}\text { The study used } \\
\text { interview } \\
\text { questionnaires } \\
\text { the samples. }\end{array}$ & Taiwan & $\begin{array}{l}304 \quad \text { Taiwan } \\
\text { National } \\
\text { Immigration } \\
\text { Agency } \\
\text { employees. }\end{array}$ & $\begin{array}{l}\text { The results showed a cross-influence } \\
\text { between the organization and the } \\
\text { individual whereby the engagement } \\
\text { of change-oriented OCB among } \\
\text { employees was not only based on the } \\
\text { variables at the individual level but } \\
\text { also can be strengthen by the variables } \\
\text { at the group level. }\end{array}$ \\
\hline 2 & $\begin{array}{l}\text { Mohit } \text { Yadav } \\
\& \quad \text { Santosh } \\
\text { Rangnekar, } \\
\text { 2016 }\end{array}$ & $\begin{array}{l}\text { The aims of this study } \\
\text { was to investigate the } \\
\text { effect of role clarity on } \\
\text { each of OCB's } \\
\text { dimensions (altruism, } \\
\text { courtesy, } \\
\text { conscientiousness, } \\
\text { sportsmanship and civic } \\
\text { virtue) as well as the } \\
\text { moderating effect of } \\
\text { tenure between role } \\
\text { clarity and OCB. }\end{array}$ & $\begin{array}{l}\text { The study used } \\
\text { management } \\
\text { development } \\
\text { programmes } \\
\text { (MDPs) as a } \\
\text { medium } \\
\text { distribute to } \\
\text { questionnaires to } \\
\text { the selected } \\
\text { samples. }\end{array}$ & India & $\begin{array}{l}300 \text { of power } \\
\text { organizations' } \\
\text { employees } \\
\text { (private and } \\
\text { public). }\end{array}$ & $\begin{array}{l}\text { The findings indicated that public } \\
\text { power organization showed better } \\
\text { role clarity-OCB relationship than } \\
\text { private power organization. Apart } \\
\text { from that, the moderating effect of } \\
\text { tenure on role clarity-OCB } \\
\text { relationship occurred only for } \\
\text { altruism, courtesy and civic virtue of } \\
\text { OCB dimensions. }\end{array}$ \\
\hline 3 & $\begin{array}{l}\text { Mukaddes } \\
\text { Yeșilkaya \& } \\
\text { Peruzet } \\
\text { Aydin, } 2016\end{array}$ & $\begin{array}{l}\text { The objective of this } \\
\text { study was to examine } \\
\text { the relationship between } \\
\text { employees' perception } \\
\text { on authentic leadership } \\
\text { and OCB. }\end{array}$ & $\begin{array}{l}\text { The study used a } \\
\text { questionnaire } \\
\text { survey method. }\end{array}$ & Turkey & $\begin{array}{l}400 \quad \text { public } \\
\text { employees }\end{array}$ & $\begin{array}{l}\text { The research proved that certain } \\
\text { attitudes of employees can lead to } \\
\text { organizational performance and } \\
\text { positive behaviours in organization. } \\
\text { There was a significant relationship of }\end{array}$ \\
\hline
\end{tabular}


employees' perception on authentic leadership with OCB.

\begin{tabular}{|c|c|c|c|c|c|c|}
\hline 4 & $\begin{array}{l}\text { Campbell, } \\
2015\end{array}$ & $\begin{array}{l}\text { The author applied } \\
\text { social identity theory by } \\
\text { linking organizational } \\
\text { identity (OI) to change- } \\
\text { oriented OCB (CO- } \\
\text { OCB) as well as to } \\
\text { explore performance } \\
\text { management (PM) - } \\
\text { OCB relationships with } \\
\text { OI as the mediator. }\end{array}$ & $\begin{array}{l}\text { The study used a } \\
\text { professional survey } \\
\text { company r to } \\
\text { administer } \\
\text { questionnaires } \\
\text { through conducting } \\
\text { face-to race } \\
\text { interviews. }\end{array}$ & $\begin{array}{l}\text { South } \\
\text { Korea }\end{array}$ & $\begin{array}{l}456 \quad \text { civil } \\
\text { servants in } \\
\text { central } \\
\text { government of } \\
\text { South Korea. }\end{array}$ & $\begin{array}{l}\text { Overall, the study suggested that PM } \\
\text { has a positive impact on CO-OCB } \\
\text { however, only through its positive } \\
\text { relationship with OI. The } \\
\text { relationships between OI and CO- } \\
\text { OCB can be explained using the } \\
\text { social identity theory which indicated } \\
\text { that when employees are able to sense } \\
\text { of belonging to the organization, then } \\
\text { they are likely to engage more in CO- } \\
\text { OCB. }\end{array}$ \\
\hline 5 & $\begin{array}{l}\text { Fakhredin } \\
\text { Taghinezhad, } \\
\text { Mahboobe } \\
\text { Safavi, } \\
\text { Afsaneh } \\
\text { Raiesifar, } \\
\text { Sayed } \\
\text { Hossein } \\
\text { Yahyavi, } \\
\text { 2015 }\end{array}$ & $\begin{array}{l}\text { The authors described } \\
\text { the antecedents of OCB } \\
\text { which were job } \\
\text { satisfaction } \\
\text { organizational } \\
\text { commitment and } \\
\text { procedural justice. }\end{array}$ & $\begin{array}{l}\text { The study used a } \\
\text { questionnaire } \\
\text { survey method. }\end{array}$ & Iran & $\begin{array}{l}373 \text { nurses in } \\
\text { Tehran }\end{array}$ & $\begin{array}{l}\text { Organizational commitment was the } \\
\text { strongest predictor to OCB and } \\
\text { procedural justice came in second. } \\
\text { Job satisfaction remained constant. }\end{array}$ \\
\hline 6 & $\begin{array}{l}\text { Park, Park \& } \\
\text { Ryu, } 2013\end{array}$ & $\begin{array}{l}\text { The authors described } \\
\text { how organizational } \\
\text { commitment and OCB } \\
\text { affected differently by } \\
\text { various types of } \\
\text { organizational trust, } \\
\text { organizational structures } \\
\text { and organizational } \\
\text { cultures. }\end{array}$ & $\begin{array}{l}\text { The study used } \\
2010 \quad \text { Korean } \\
\text { Central } \\
\text { Government Survey } \\
\text { data in order to } \\
\text { select samples } \\
\text { randomly and } \\
\text { distributing } \\
\text { questionnaires }\end{array}$ & $\begin{array}{l}\text { South } \\
\text { Korea }\end{array}$ & $\begin{array}{l}1,122 \text { public } \\
\text { employees } \\
\text { within } 40 \\
\text { ministries and } \\
\text { public agencies. }\end{array}$ & $\begin{array}{l}\text { Relating to OCB, the results showed } \\
\text { that organizational trust (supervisor } \\
\text { and colleagues, organizational } \\
\text { structures (formalized and } \\
\text { centralized) and organizational } \\
\text { cultures (group and developmental } \\
\text { culture) positively affect OCB. }\end{array}$ \\
\hline
\end{tabular}


7 Vashdi, The authors examined The study used a Israel Vigoda-Gadot multiple-climate of questionnaire

\& Shlomi, organizational climate survey method. 2012

as the factors that lead to

micro-level performance

such as job satisfaction,

exit and group level

OCB (GOCB).

2,102 teachers.

Based on the results relating to group level OCB (GOCB), service climate and participative climate encouraged public employees to engage in GOCB at the micro-level. Apart from that, GOCB has impact on the school achievement among students at macro-level.

\begin{tabular}{|c|c|c|c|c|c|}
\hline 8 & Cun, 2012 & $\begin{array}{l}\text { The purpose of this } \\
\text { study is to examine the } \\
\text { influence of public } \\
\text { service motivation } \\
\text { (PSM) on job } \\
\text { satisfaction and OCB. }\end{array}$ & $\begin{array}{l}\text { The study used a } \\
\text { questionnaire } \\
\text { survey method. }\end{array}$ & $\begin{array}{l}502 \text { public } \\
\text { employees in } \\
\text { Guangzhou. }\end{array}$ & $\begin{array}{l}\text { Public reason and public norm were } \\
\text { the two components in PSM that } \\
\text { significantly influenced job } \\
\text { satisfaction and OCB among } \\
\text { Guangzhous' public employees. }\end{array}$ \\
\hline 9 & $\begin{array}{l}\text { Chih, Yang \& } \\
\text { Chang, } 2012\end{array}$ & $\begin{array}{l}\text { The study examined } \\
\text { OCB based on job } \\
\text { satisfaction, } \\
\text { organizational } \\
\text { commitment and } \\
\text { attitude toward } \\
\text { organizational change as } \\
\text { its antecedents. }\end{array}$ & $\begin{array}{l}\text { The questionnaires } \\
\text { were divided into } \\
\text { two pretest; to test } \\
\text { the reliability and to } \\
\text { ensure } \\
\text { measurement the } \\
\text { effectiveness. After } \\
\text { the pretests, the } \\
\text { formal } \\
\text { questionnaire was } \\
\text { distributed. }\end{array}$ & $\begin{array}{l}450 \text { Republic of } \\
\text { China Armed } \\
\text { Force }\end{array}$ & $\begin{array}{l}\text { The antecedents of this study were } \\
\text { proven to have a positive impact on } \\
\text { OCB. This means that the soldiers } \\
\text { were likely to engage in OCB } \\
\text { whenever they felt satisfied in their } \\
\text { jobs as well as have a positive attitude } \\
\text { toward organizational change. }\end{array}$ \\
\hline 10 & Kim, 2012 & $\begin{array}{l}\text { The objective of this } \\
\text { study was to investigate } \\
\text { the causal relationship } \\
\text { between } \\
\text { transformational } \\
\text { leadership and OCB by }\end{array}$ & 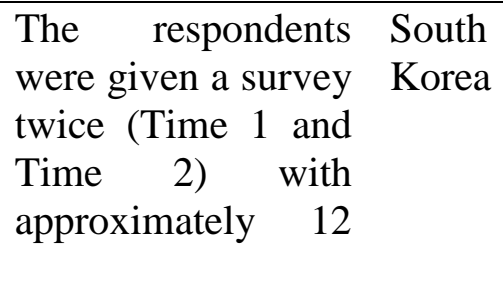 & $\begin{array}{l}198 \text { full-time } \\
\text { employees of the } \\
\text { Jellanam-Do } \\
\text { government. }\end{array}$ & $\begin{array}{l}\text { The findings showed indirect } \\
\text { relationship between transformational } \\
\text { leadership and OCB in which the } \\
\text { relationship mediated by affective } \\
\text { commitment. The findings showed } \\
\text { inconsistent results from the previous }\end{array}$ \\
\hline
\end{tabular}


exploring the role of weeks gap between affective commitment as the surveys.

the mediating role. studies due to the cultural characteristic of collectivism in Korean government.

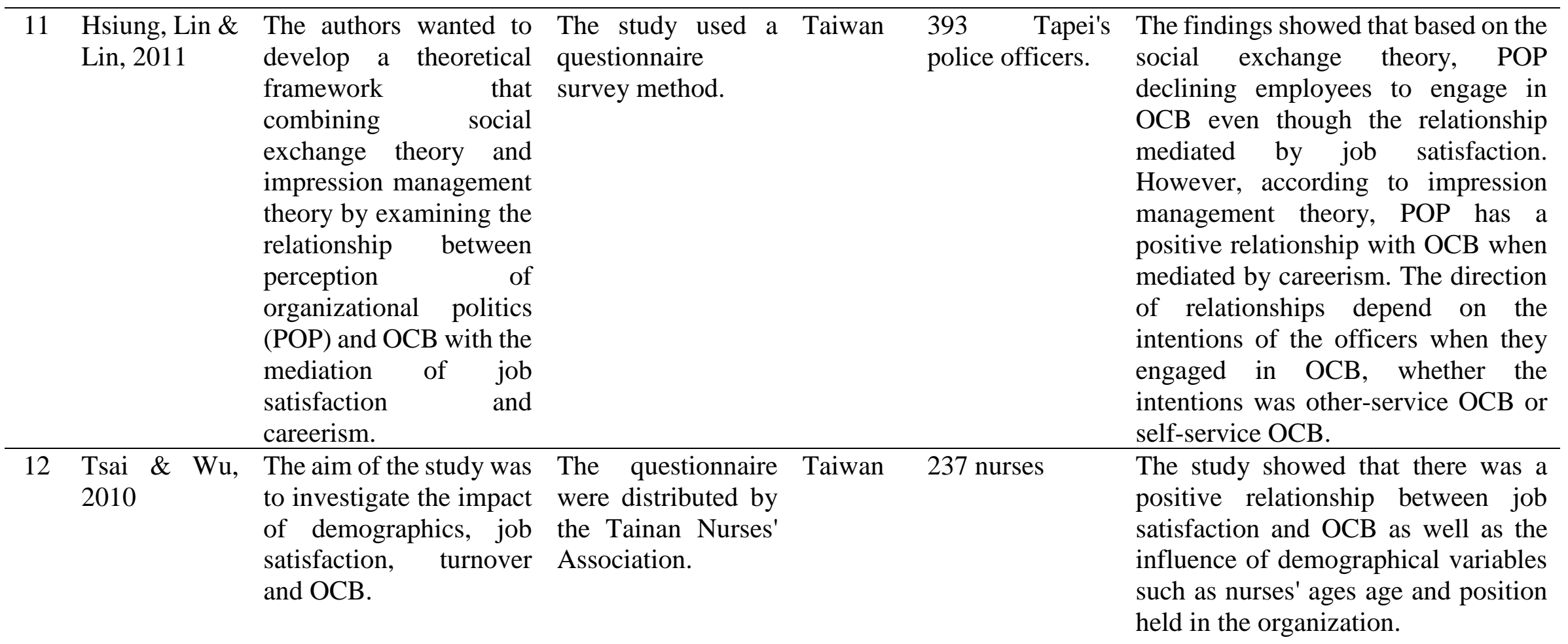

Studies of OCB conducted in Malaysia 


\begin{tabular}{|c|c|c|c|c|c|c|}
\hline No. & $\begin{array}{l}\text { Author and } \\
\text { date }\end{array}$ & Research objectives & Research design & $\begin{array}{l}\text { Country } \\
\text { of origin }\end{array}$ & Sample & Findings \\
\hline 1 & $\begin{array}{l}\text { Ayu } \\
\text { Kamareena } \\
\text { Abdullah } \\
\text { Thani \& } \\
\text { Abdul Kadir } \\
\text { Othman, } 2018\end{array}$ & $\begin{array}{l}\text { The aim of the study was } \\
\text { to examine the role of } \\
\text { work engagement as the } \\
\text { moderator in P-E fit and } \\
\text { OCB relationship. }\end{array}$ & $\begin{array}{l}\text { A questionnaire } \\
\text { survey was used to } \\
\text { collect the data for } \\
\text { this study. }\end{array}$ & Malaysia & $\begin{array}{l}371 \\
\text { servants }\end{array}$ & $\begin{array}{l}\text { Results supported the role of work } \\
\text { engagement as the moderator between } \\
\text { P-E fit and OCB whereby work } \\
\text { engagement moderates the } \\
\text { relationship of person-job fit, person- } \\
\text { organization fit and person-supervisor } \\
\text { fit with OCB. }\end{array}$ \\
\hline 2 & $\begin{array}{l}\text { Junaidah } \\
\text { Yusof, } \\
\text { Hashim Fauzy } \\
\text { Yaacob \& Siti } \\
\text { Aisyah Abd } \\
\text { Rahman, } \\
2018\end{array}$ & $\begin{array}{l}\text { The objective of this } \\
\text { study was to investigate } \\
\text { the relationship between } \\
\text { workplace spirituality } \\
\text { with all of five } \\
\text { dimensions of OCB. }\end{array}$ & $\begin{array}{l}\text { The study used a } \\
\text { questionnaire } \\
\text { survey method. }\end{array}$ & Malaysia & $\begin{array}{l}475 \text { nurses from } \\
\text { public hospitals. }\end{array}$ & $\begin{array}{l}\text { Meaningful work, sense of } \\
\text { community and organizational values } \\
\text { alignment in workplace spirituality } \\
\text { dimension was found significantly } \\
\text { affected courtesy in OCB while only } \\
\text { two of workplace spirituality } \\
\text { dimensions (sense of community and } \\
\text { organizational values alignment) } \\
\text { affected conscientiousness. Altruism } \\
\text { was influenced by meaningful work } \\
\text { and organizational values alignment } \\
\text { dimensions. }\end{array}$ \\
\hline 3 & $\begin{array}{lr}\text { Nik } & \text { Nadian } \\
\text { Nisa Nik } \\
\text { Nazli \& } \\
\text { Sheikh } \\
\text { Muhamad } \\
\text { Hizam Sheikh } \\
\text { Khairudin, } \\
2018\end{array}$ & $\begin{array}{l}\text { The authors wanted to } \\
\text { investigate the } \\
\text { mediating effect of } \\
\text { transfer of training } \\
\text { (ToT) between the } \\
\text { independent variables } \\
\text { (organizational learning } \\
\text { culture, psychological } \\
\text { contract breach, work } \\
\text { engagement and training } \\
\text { simulation) and OCB. }\end{array}$ & $\begin{array}{l}\text { This study focused } \\
\text { on the target group } \\
\text { whereby only those } \\
\text { who participated in } \\
\text { disaster } \\
\text { preparedness } \\
\text { training } \\
\text { programmes } \\
\text { received the } \\
\text { questionnaires. }\end{array}$ & Malaysia & $\begin{array}{lr}356 & \text { employees } \\
\text { at } & \text { Malaysia } \\
\text { Civil } & \text { Defense } \\
\text { Force (APM) }\end{array}$ & $\begin{array}{l}\text { The results showed that ToT played } \\
\text { the role of mediator between work } \\
\text { engagement and OCB as well as } \\
\text { training simulation and OCB. This } \\
\text { means that employees who were } \\
\text { highly engaged in work as well as } \\
\text { engaged in training simulation were } \\
\text { more likely to engage in OCB } \\
\text { whenever they were willingly to } \\
\text { transfer new knowledge, skills and } \\
\text { attitude learned from training. }\end{array}$ \\
\hline
\end{tabular}


4 Subramaniam The authors wanted to Mail survey method Malaysia 153

Sri Ramalu \& construct a mediated was used in this servants

Zulhusni

Mohamad

Rashid, 2017

model of employee study.

engagement in the

relationship between

Islamic work ethic and

OCB.

5 Noorlaila The authors wanted to

Yunus \& examine the strongest

Cairul Azwa predictors of Herzberg's

Azimi, 2016

OCB.
OCB. civil The findings supported the model whereby when the employees have a high level of Islamic work ethic, they were likely to engage in OCB and this relationship was strengthen through employee engagement.

The study was Malaysia 125

designed was

descriptive

as

Malaysia$$
\text { employees. }
$$

correlational study

using survey

method.
The study showed that Herzberg's motivator factors can predict OCB such as achievement in Hezberg's motivator factor influenced on altruism in OCB dimension as well as growth in Herzberg's motivator factor was the strongest predictor for conscientiousness and courtesy in OCB dimensions. None of herzberg's motivator factors predicted other dimensions in OCB.
6 Ibrahim, Aziz The objective of the The study used a Malaysia Amin, Ghani, study was to investigate questionnaire Hashim \& OCB based on five survey method. Salleh, 2015 demographical variables; gender, supervisor's gender, organizational type, organizational seniority and dyadic tenure.
222 employees southern part of Malaysia.

public Not all demographical variables were

in able to explained and influenced OCB. The study showed that only organizational type (municipal council and district council has stronger OCB than city council) and dyadic tenure (less than 5 years showed lower OCB than 11 to 15 years of supervision) influenced OCB. 
7 Fatimah, Amira

The aim of this study

\& was to examine the moderating effect of

OCB between

organizational justice and job satisfaction.
Halim, 2011

A questionnaire survey was used to collect the data for this study.

$8 \quad$ Jehad

Mohammad,

The authors

Farzana

Quoquab

Habib investigate

$\mathrm{OCB}$

to Self-administered

examined

its two used in this study. dimensions (OCBI and

\& OCBO) been affected by the two dimensions of

Adnan Alias, job satisfaction (intrinsic 2011 and extrinsic).

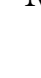

Malaysia

Malaysia 169 public The results indicated that only school teachers altruism and civic virtue in OCB's dimensions have a strong predictor towards job satisfaction. Apart from that, OCB moderates the relationship between organizational justice (procedural justice and interactional justice) and job relationship

public The findings showed different results from the previous literatures whereby there was a positive relationship between both of job satisfaction's dimensions with OCBO but not OCBI. 
The antecedents of OCB among nurses and public health setting in this review focused on the employee attitudes and demographical variables as well as workplace spirituality and motivation. These were aligned with other previous studies which showed employee characteristics domain were most being frequently observed and reported to OCB (Shim \& Rohrbaugh, 2014).

\section{OCB among Public Employees in Office-Based Settings}

The review in this section starts with a study done by Mohit Yadav and Santosh Ragnekar (2016) among employees who work in the public power sector organization in India. They found that employee role perception such as role clarity influenced the engagement of OCB among employees (Mohit Yadav et. al, 2016). This means that employees would engage in OCB whenever they are understand their job scope and know what they need to do in their jobs. In fact, the relationship between role clarity and OCB was moderated by tenure which means that role clarity was positively influenced OCB with the increased in tenure level in employees (Mohit Yadav et. al, 2016).

Apart from transformational leadership which have influence on the occurrence of OCB (Kao, 2017; Kim, 2012), another form of leadership proves to have the same effect which is authentic leadership (Mukaddes Yeșilkaya \& Peruzet Aydin, 2016). Individuals with authentic leadership behaviours tend to have a greater self-awareness of their own strengths and weaknesses which help them to be true to themselves as well as motivating followers to trigger self-discovery for further positive development and growth (Mukaddes Yeșilkaya et. al, 2016). It is believed that authentic leaders perform OCB which influence the followers to do the same. It is explained by Jacques, Garger, Lee and Ko, (2015) that employees who are working with managers or employers with authentic leadership style would show attitudes and behaviours similar to the leaders.

Another antecedent of OCB which was found in this review fall under the category of task/ job domain. This can be seen in a study done by Campbell (2015) on the effect of performance management on change-oriented OCB among civil servants working in ministry of South Korea government. Performance management at the employee level guide employees to execute a better job performance. This begins with a clear set of goals or tasks that need to be achieves, a good performance appraisals as well as compromising rewards whenever the goal or tasks have been achieved (Campbell, 2015). A systematic performance management was positively related to change-oriented OCB (Campbell, 2015). This means that if the employees understand on what they need to achieve in their jobs as well as having a constructive feedback on their works, there would be a high likelihood for them to perform their jobs beyond the basic requirements and that has been categorizing as engage in OCB.

Another study done among Korean civil servants found that the conditions of the organization did have a positive effect on the performance of OCB (Park, Park \& Ryu, 2013). Organizational trust, organizational structure and organizational culture have a significant impact on OCB (Park, et. al, 2013). The study aligned with the previous literatures which showed that gaining trust from supervisor and colleagues influence the employees to work harder as well as exceed the formal requirement of the job. However, the study refuted the previous literature which stated that OCB levels is more likely higher in less structured organization. The study showed that formalized and centralized of organizational structure leads to engagement of OCB among its employees (Park, et. al, 2013). This is due to differences between Western and Asian norms and work cultures. 
The antecedents of OCB in this type of setting covers each of the four domains proposed by Podsakoff et. al, (2000) in their study. The review discussed on employee role perception which was role clarity that falls under employee characters domain. Then there was authentic leadership which falls under leadership behaviours domain. After that, there was performance management which categorized under task/ job dimensions domain and lastly organizational trust, organizational structures and organizational cultures which were categorized under organizational conditions domain.

\section{Other Antecedents of OCB in Malaysia and Asian Studies}

Most of the antecedents in this review fall under Podsakoff's four domains of OCB's antecedents which are employee characteristic, task characteristics, organizational conditions and leadership behaviour (Podsakoff, et. al, 2000). Having said that, there were several studies in Malaysia and other Asian countries which examined variables that are not categorized under these four domains but can guide researchers to another different perspective in examining OCB's antecedents.

The first review in this section begins with a study examining the relationship between personenvironment (P-E) fit and OCB with the moderating role of work involvement (Ayu Kamareena, et. al, 2018). Based on the study, they found that work involvement can strengthen the relationship between P-E fit and OCB thus when work involvement among employees is high, it can trigger employees to engage in OCB regardless of low effect or high effect of P-E fit (Ayu Kamareena, et. al, 2018). By referring back to P-E fit definition, it refers to the degree of compatibility between individuals and the place where the individuals work. This means that the compatibility depends whether the person's knowledge, skills, abilities and other traits are match with the work environment which consists of job characteristics and organization characteristics. Therefore clashes between person and environment is a sign of the downfall of organization efficiency and performance moreover performing OCB. By integrating work involvement as the moderating variable provides a good empirical evidence as well as guiding researchers for future research in P-E fit and OCB relationship thus expanding more on the literatures of OCB's antecedents.

Another review in this section examined motivation-based as the antecedent of OCB. Motivation is an internal drive that makes individuals move towards attaining goals. Previous studies found out that motivation have a positive influence on OCB regardless of the types of motivation been studied (Hemakumara, Khatibi \& Md Gapar Md Johar, 2018; Mushtaq \& Umar, 2015; Barbuto, Jr \& Story, 2011). In this review, a study done by Cun (2012) examined the effect of public service motivation (PSM) on OCB among employees working in the public sectors. PSM originates from beliefs that public servants are different from those who are working in the private sectors in terms of motives that guide them to deliver their services to the community (Perry, Hondeghem \& Wise, 2010). According to Cun (2012), PSM significantly influenced OCB in terms of its public reason and public norm. The employees believed that the reason they involved working in the public sectors was due to wanting to contribute to the society in terms of giving better quality of services. Therefore OCB was part of their contributions for a better quality of services. Moreover, PSM has been associated with the altruistic motivation which guide them to serve better toward the interest of a community of people and nations (Perry, et. al, 2010). Another motivation-based antecedent done in a study by Noorlaila Yunus, et. al, (2016) in which they examined Herzberg's motivator factor (achievement and growth components). The study predicted that achievement and growth components in Herzberg's motivator factor motivates nurses to engage in OCB especially in altruism component (Noorlaila Yunus, et. al, 2016). The presence of motivator factors altruistic 
behaviours among employees because it constantly fulfilled the highest need of intrinsic rewards of self-actualization (Noorlaila Yunus, et. al, 2016) to increase welfares of others.

Another study of OCB's antecedents that was covered in this review was Islamic work ethic. Though work ethic can be categorized under employee characteristics domain, Islamic work ethic has a different view as religion plays a vital role that shape individuals in every aspects of life including moral principles related to work. A study done by Subramaniam Sri Ramalu and Zulhusni Mohamad Rashid (2017) showed that Islamic work ethic influenced OCB with the presence of employee engagement as the mediator. This study showed that employees who followed the principles of Islam tend to demonstrate positive and proactive behaviours in the organization (Subramaniam Sri Ramalu et, al, 2017). This includes willingness to help others and work beyond prescribed work requirements. Another study that focused on the moral principles and values related to work that have connection with OCB is workplace spirituality. Though it is not related to any belief in religion but somehow it relates to a belief that employees are both physical and spiritual beings seeking to find meaning and purpose in their work. It relates to meaningful work, relates to the community at their workplace and align with organizational values (Junaidah Yusof, et. al, 2018). Employees who have higher level of workplace spirituality found their purposes in their working life and have the tendency to be willingly committed to their works and engage in OCB (Junaidah Yusof et. al, 2018).

\section{Conclusion}

This scoping review focused on the antecedents of OCB which had been studied among public or civil employees in Malaysia and other Asian countries. Based on the reviews performed, the antecedents of OCB were classified based on the three different work settings which were law enforcement and military settings, nurses and public health settings and lastly office-based settings. Though the reviews of OCB was based on the different setting, the explanation of the antecedents of OCB was based on the Podsakoff's four domains of OCB's antecedents which are employee characteristic, task characteristics, organizational conditions and leadership behaviour (Podsakoff, et. al, 2000). Therefore, there would be a repetition of explanation regarding the factors that caused employees engaged in OCB in the three settings.

The review also found other factors of OCB (P-E fit, PSM, Herzberg's motivation factor, Islamic work ethic and workplace spirituality) which are beneficial to be investigated further and integrated with other variables which moderating or mediating the relationships between the antecedents and OCB. The review suggests that these type of factors to be investigated more in the Asian countries context as culture and traditions play a vital roles in influencing individuals' perspectives in their daily life and even in working life. Moreover, the findings of this investigation can address certain gaps thus adding to the knowledge and literatures regarding to OCB.

\section{Acknowledgement}

The author would like to thank Universiti Malaysia Sabah for granting permission to study leave and would like to thank colleagues from Fakulti Psikologi dan Pendidikan, Universiti Malaysia Sabah who provided insight and expertise that greatly assisted the research in this paper.

\section{References}

Atatsi, E., Stoffers, J., \& Kil, A. (2019). Factors affecting employee performance: a systematic literature review, Journal of Advances in Management Research, Vol. 16 No. 3, 329351. 
Arksey, H., \& O’Malley, L. (2005). Scoping studies: Towards a methodological framework. International Journal of Research Methodology, 8, 19-32.

Ayu Kamareena Abdullah Thani \& Abdul Kadir Othman. (2018). The moderating role of work involvement in influencing the relationship between person-environment fit and organizational citizenship behaviour among public service employees. Advances in Research International Journal, 53-66.

Barbuto, Jr. J. E., \& Story, J. S. P. (2011). Work motivation and organizational citizenship behaviors. A field study. Journal of Leadership Studies. Volume 5, Number 1, 23-34.

Basu, E., Pradhan, R. K., \& Tewari, H. R. (2017). Impact of organizational citizenship behaviour on job performance in Indian healthcare industries. International Journal of Productivity and Performance Management, 66(6), 780-796.

Campbell, J. W. (2015). Identification and performance management: An assessment of change-oriented behaviour in public organizations. Public Personnel Management, Vol. 44(1), 46-69.

Chiaburu D. S., Chakrabarty, S., Wang, J., \& Li, N. (2015). Organizational support and citizenship behaviours: A comparative cross-cultural meta-analysis. Management International Review, 55: 707-736.

Chih, W-H. W., Yang, F-H., \& Chang, C-K. (2012). The study of the antecedents and outcomes of attitude toward organizational change. Public Personnel Management, 41, 4, 597617.

Cun, X. (2012). Public service motivation and job satisfaction, organizational citizenship behaviour. An empirical study based on the sample of employees in Guangzhou public sectors. Chinese Management Studies, Vol. 6, No. 2, 330-340.

Fatimah, O., Amiraa, A. M., \& Halim, F. W. (2011). The relationships between organizational justice, organizational citizenship behaviour and job satisfaction. Pertanika J. Soc. Sci. \& Hum, $19(S)$ : 115-121.

Fakhredin Taghinezhad, Mahboobe Safavi, Afsaneh Raiesifar, \& Sayed Hossein Yahyavi. (2015). Antecedents of organizational citizenship behaviour among Iranian nurses: A multicentre study. BMC Res. Notes, 8:547, 1-8.

George, J. M., \& Brief, A. P. (1992). Feeling good-doing good: A conceptual analysis of the mood at work-organizational spontaneity relationship. Psychology Bulletin, 112, 310329.

Hemakumara, M. G. G., Khatibi, A. A., \& Md Gapar Md Johar. (2018). Effect of motivation on organizational citizenship behaviour among administrative staff of state universities in Sri Lanka. European Journal of Business and Management, Vol. 10, No. 23, 29-32.

Hsiung, H-H., Lin, C-W., \& Lin, C-S. (2011). Nourishing or suppressing? The contradictory influences of perception of organizational politics on organizational citizenship behaviour. Journal of Occupational and Organizational Psychology, 85, 258-276

Ibrahim, R., Aziz Amin, A., Ghani, M. A., Hashim, N., \& Salleh, M. (2015). Organisational citizenship behaviour readiness: A demographic study on local government employees in Southern Region of Malaysia. Pertanika J. Soc. Sci. \& Hum, 23(S): 51-62.

Jacobs, S. (2016). A scoping review examining nursing student peer mentorship. Prof Nurs 33:212-223.

Jehad Mohammad, Farzana Quoquab Habib \& Mohmad Adnan Alias, (2011). Job satisfaction and organisational citizenship behaviour: An empirical study at higher learning institutions. Asian Academy of Management Journal, Vol. 16, No. 2, 149-165.

Junaidah Yusof, Hashim Fauzy Yaacob, \& Siti Aisyah Abd Rahman. (2018). The relationship of workplace spirituality on organizational citizenship behaviour. Sains Humanika, 10:2, 31-39. 
Katz, D. (1964). The motivational basis of organizational behaviour. In George, J. M., \& Brief, A. P. (1992). Feeling good-doing good: A conceptual analysis of the mood at workorganizational spontaneity relationship. Psychology Bulletin, 112, 310-329.

Kim, H. (2012). Transformational leadership and organisational cirizenship behaviour in the public sector in South Korea: The mediating role of affective commitment. Local Government Studies, Vol. 38, No. 6, 867-892.

Kim, T., Park, S., \& Chang, K. (2011). Antecedents of organizational citizenship behaviours among part-time employees of service organizations in Korea. Asia Pacific Business Review, Vol. 17, No. 1, 85-101.

Kao, R-H. (2017).The relationship between work characteristics and change-oriented organizational citizenship behaviour. A multi-level study on transformational leadership and organizational climate in immigration workers. Personnel Review, Vol. 46, No. 8, 1890-1914.

Lam, C. F., Wan, W. H., \& Roussin, C. J. (2016). Going extra mile and feeling energized: An enrichment perspective of organizational citizenship behaviours. Journal of Applied Psychology, Vol.101, No.3, 379-391.

Lavy, S., \& Littman-Ovadia, H. (2016). My Better Self: Using Strengths at Work and Work Productivity, Organizational Citizenship Behaviour, and Satisfaction. Journal of Career Development, 0894845316634056

Mohit Yadav \& Santosh Rangnekar. (2016). Role clarity and organizational citizenship behaviour: Does tenure matter? A study on Indian power sector. Global Business Review, 17(3S), 1S-18S

Mukaddes Yeșilkaya \& Peruzet Aydin. (2016). Do employees' perceptions on aunthentic leadership affect the organizational citizenship behaviour? : Turkish context. Journal of International Education and Leadership, Volume 6, Issue 1, 1- 13.

Mushtaq, K., \& Umar, M. (2015). Association between job satisfaction, motivation and five factors of organizational citizenship behavior. International Journal of Psychology and Behavioral Sciences, Vol. 9, No. 8, 2872-2878.

Nik Nadian Nisa Nik Nazli \& Sheikh Muhamad Hizam Sheikh Khairudin. (2018). The factors that influence transfer of training and its effect on organizational citizenship behaviour: Evidence from Malaysia civil defence force. Journal of Workplace Learning, Vol. 30, No. 2, 121-146.

Noorlaila Yunus \& Cairul Azwa Azimi. (2016). The influence of Herzberg's motivator factor on employees' organizational citizenship behaviour. Advances in Business Research International Journal, Volume 2, No. 1, 1-13.

Organ, D. W. (1997). Organizational citizenship behaviour: It's construct clean-up time. Human Performance, 10(2), 85-97

Park, S. M., Park, H. J., \& Ryu, E. Y. (2013). Determinants of positive job attitude and behaviour in the Asian work context. Evidence from Korean central government agencies. Public Management Review, Vol. 15, No. 8, 1154-1184.

Perry, J. L., Hondeghem, A., \& Wise, L. R. (2010). Revisiting the motivational base of public service: Twenty years of research and an agenda for the future. Public Administration Review, 70, 5, 681-690.

Peters, M. DJ., Godfrey, C. M., Hanan Khalil, McInerny, P., Parker, D., \& Soares, C. B. (2015). Guidance for conducting systematic scoping reviews. International Journal of Evidence Based Health Care, 13, 141-146.

Peterson, J., Pearce, P. F., Ferguson, L. A., \& Longford, C. A. (2017). Understanding scoping reviews: Definition, purpose and process. Journal of the American Association of Nurse Practitioners, 29, 12-16. 
Podsakoff, P. M., MacKenzie, S. B. (1997). The impact of organizational citizenship behaviour on organizational performance: A review and suggestions for future research. Human Performance, 10: 133-151.

Podsakoff, P. M., MacKenzie, S. B., Paine, J. B., \& Bachrach, D. G. (2000). Organizational citizenship behaviours: A critical review of the theoretical and empirical literature and suggestions for future research. Journal of Management, Vol.26, No.3, 513-563.

Shim, D. C., \& Rohrbaugh, J. (2014). An explanation of differences between government offices in employees' organizational citizenship behaviour. Public Management Review, Vol. 16, No. 6, 807-829.

Smith, C. A., Organ, D. W., \& Near, J. P. (1983). Organizational citizenship behaviour: Its nature and antecedents. Journal of Applied Psychology, Vol 68, No. 4, 653-663.

Subramaniam Sri Ramalu \& Zulhusni Mohamad Rashid. (2016). Islamic work ethic and organizational citizenship behaviour: a study among civil servants in Malaysia. South East Asia Journal of Contemporary Business, Economics and Law, 11(2).

Tsai, Y., \& Wu, S-W. (2010). The relationships between organisational citizenship behaviour, job satisfaction and turnover intention. Journal of Clinical Nursing, 19, 3564-3574.

Vashdi, D. R., Vigoda-Gadot, E., \& Shlomi, D. (2012). Assessing performance: The impact of organizational climates and politics on public schools' performance. Public Administration. DOI: 10.1111/j.1467-9299.2011.01968.

Vigoda-Gadot, E., \& Beeri, I. (2012). Change-oriented organizational citizenship behaviour in public administration: The power of leadership and the cost of organizational politics. Journal of Public Administration Research and Theory, 22, 573-596.

Wu, C-C., \& Liu, N-T. (2014). Perceived organizational support, organizational commitment and service-oriented organizational citizenship behaviours. International Journal of Business and Information, Vol. 9, No. 1, 61-88. 